Dialectologia. Special issue, V (2015), 351-371.

ISSN: 2013-2247

Received 23 April 2015.

Accepted 31 July 2015.

\title{
PREDICATIVE CONSTRUCTIONS WITH GERUNDS IN EUROPEAN PORTUGUESE DIALECTS ${ }^{1}$
}

\author{
Sílvia Afonso Pereira \\ Centro de Linguística da Universidade de Lisboa \\ Faculdade de Letras da Universidade de Lisboa \\ silvia.a.pereira@gmail.com
}

\begin{abstract}
This study analyzes dialectal data collected from CORDIAL-SIN, an annotated corpus of Portuguese dialects, and addresses predicative constructions with gerunds: a non-standard construction found in some European Portuguese dialects, which is equivalent to the standard Portuguese structure where a preposition followed by an infinitive is used. I show that this non-standard construction is geographically confined to the south of Portugal and some insular dialects. This type of geographic distribution has been identified in previous works on dialect syntax, and my data now brings additional evidence to support the hypothesis that it seems to correspond to a basic division of Portuguese dialects. This geographic distribution highlights that predicative gerunds are, along with progressive gerunds with estar 'to be', a clear example of syntactic alternation in European Portuguese between gerunds and prepositional infinitives.
\end{abstract}

Keywords

syntactic variation, predicative gerunds, dialect syntax, Portuguese dialects, syntactic areas

\section{O GERÚNDIO PREDICATIVO EM DIALETOS DO PORTUGUÊS EUROPEU}

Resumo

Este trabalho analisa dados dialetais reunidos no CORDIAL-SIN, um corpus anotado para o estudo da sintaxe dialetal portuguesa, e centra-se no estudo de construções predicativas com gerúndios: uma

\footnotetext{
${ }^{1}$ This work was supported by Fundação para a Ciência e a Tecnologia (FCT) grant SFRH/BD/81062/2011.
} 
estrutura não-padrão identificada em alguns dialetos do português europeu, equivalente à construção com infinitivo preposicionado utilizada no português padrão. Mostra-se que esta construção não-padrão se confina geograficamente a localidades do sul do território português e a alguns dialetos insulares. Este tipo de distribuição geográfica foi identificado em trabalhos anteriores sobre sintaxe dialetal, e o presente trabalho traz novos argumentos no sentido de se defender que este tipo de distribuição representa uma divisão básica dos dialetos portugueses. A distribuição geográfica identificada neste trabalho sublinha que o gerúndio predicativo constitui, tal como a construção de estar aspetual+gerúndio, um exemplo claro de variação sintática entre gerúndios e infinitivos preposicionados em português europeu.

\section{Palavras-chave}

variação sintática, gerúndios predicativos, sintaxe dialetal, dialetos portugueses, áreas sintáticas

\section{Introduction}

It has become clear over the past several years that dialect syntax is influenced by both syntax and dialectology. ${ }^{2}$ In Portugal, several studies based on the dialectal corpus CORDIAL-SIN (Corpus Dialetal para o Estudo da Sintaxe) have shown encouraging results, many suggesting the existence of non-standard constructions confined to specific geographic areas.

I utilize dialectal data collected from CORDIAL-SIN, an annotated corpus of Portuguese dialects, and analyze a non-standard construction found in European Portuguese (EP) dialects: predicative constructions with gerunds as in (1), which is equivalent to the standard Portuguese structure in (2) in which the infinitive is used.

$\begin{array}{cccc}\text { 1. A } & \text { rapariga } & \text { saiu } & \text { cantando. } \\ \text { The } & \text { girl } & \text { went.out } & \text { singing.GER }\end{array}$

'The girl went out singing.'

2. A rapariga saiu a cantar.

The girl went.out to sing.INF

'The girl went out singing.'

\footnotetext{
${ }^{2}$ Cf. http://www.dialectsyntax.org.
} 
My aim is to characterize non-standard gerund constructions like (1) and address some aspects that I believe contribute to a clearer discussion of predicative gerunds. Moreover, I will describe the geographical distribution of these structures within Portuguese territory.

To accomplish this, I focus on constructions with a clear predicative interpretation (such as (1)). Periphrastic constructions such as (3) and adverbial gerunds as in (4) will not be considered. ${ }^{3}$

$\begin{array}{lllll}\text { 3. } & \text { menina } & \text { está brincando no } & \text { jardim. } \\ \text { The girl } & \text { is } & \text { playing.GER in.the garden }\end{array}$

'The girl is playing in the garden.'

4. A aluna surpreendeu o professor resolvendo o problema. 'The student surprised the teacher by.solving.GER the problem.'

I will show that the predicative constructions under discussion are confined to a specific geographic area (the same area identified by Carrilho \& Pereira (2011) for periphrases with estar+GER), and that that area seems to be a recurrent dialectal division in EP dialects (cf. Pereira, in preparation). Also, I will make some observations regarding the gerund versus prepositional infinitive alternation and endeavour to relate the present day situation in Portugal with a diachronic evolution.

The paper is organized in 5 sections. In section 2 I present the empirical basis of this study: the dialectal corpus CORDIAL-SIN. Section 3 deals with previous works on predicative gerunds and section 4 with my data from CORDIAL-SIN. Conclusions are presented in section 5 .

\section{CORDIAL-SIN: data from a dialect corpus}

CORDIAL-SIN is a syntactically annotated corpus of spoken EP dialects. It compiles a geographically representative selection of spontaneous and semi-directed

\footnotetext{
${ }^{3}$ I will however mention these structures later in this study, when their observation is relevant for clarifying some ideas.
} 
speech $(600,000$ words) from 42 locations within the Portuguese territory (both continental and insular). ${ }^{4}$ The informants have the sociological profile of traditional dialectal informants: old, non-educated, rural, and those born and raised in place of interview.

The occurrences under inspection have been obtained through concordances on the tagged corpus, yielding a set of 2,095 instances of gerunds, which were analysed for pertinence to this study (i.e. disregarding periphrastic and adverbial gerunds)..$^{5}$ In some cases, excluding adverbial instances of gerund ended up being a difficult task because of the well-known ambiguity of some examples (cf. sections 3 and 4). Accordingly, I adopted the test suggested by Lobo $(2002,2003)$ for Portuguese to identify predicative constructions: predicative gerunds (cf. (5)), can occur as a prepositional infinitive in EP, but not adverbial ones (cf. (6)), according to Lobo:

5. $O$ João chegou a casa coxeando / a coxear.

The João arrived at home limping.GER to.PREP limp.INF

'João came home limping.'

6. Os ladrões entraram em casa arrombando /

The thieves entered in house breaking.GER

$\begin{array}{cccc}{ }^{*} \boldsymbol{a} & \text { arrombar } & a & \text { porta com um maçarico. } \\ \text { at.PREP } & \text { breaking.down.INF the door with a blow.torch }\end{array}$

'The thieves entered the house using a blow torch to open the door.'

After applying this test, I obtained 54 instances of the predicative gerund, which will be analysed in the following sections. ${ }^{6}$

\footnotetext{
${ }^{4}$ It compiles oral interviews gathered from the mid-seventies until 2002 by the Research Group on Linguistic Variation at Centro de Linguística da Universidade de Lisboa within the scope of several linguistic atlases projects.

5 "Concordances on the corpus were generated using the program Concordance for Windows NT4.0/2000/XP (Copyright (C) R.J.C.Watt 1999, 2000, 2002)."

${ }^{6}$ In line with what Fernández Lagunilla (1999) mentions, CORDIAL-SIN also showed that some structures can be ambiguous and fall between a predicative gerund and a periphrastic construction. I found some examples of this situation, which I subsequently disregarded due to that structural ambiguity.
} 
Dialectologia. Special issue, $\boldsymbol{V}$ (2015), 351-371.

ISSN: 2013-2247

\section{Predicative gerund: previous works on the subject}

Before exploring the data from CORDIAL-SIN, let us first consider some works on predicative gerund. Even though there is not a long tradition in studying topic, we can find some relevant studies which have been developed over the last years. ${ }^{7}$

Borgonovo (1996) and Di Tullio (1998) offer a syntactic analysis of Spanish gerunds within the generative work. Borgonovo focuses on perception constructions, which she analyses as VP adjuncts. Di Tullio, following Cinque's account for Italian pseudorelative constructions, states that depending on the context the gerund may be associated with three different structures: two single constituents, one single clausal constituent, and a complex NP.

Casalicchio also studies this topic, focusing not only on Italian dialects but offering also a wide analysis on romance predicative gerunds (cf. Casalicchio 2013). He argues that the predicative gerund can be analysed as the result of an incorporation of the verb + a null preposition, and also associates it with $\mathrm{CP}^{8}{ }^{8}$

I will not provide a syntactic analysis of these structures in this study as I focus on a more descriptive account, centring on the presentation of mainly descriptive works such as Fernández Lagunilla (1999) and Lobo $(2002,2003){ }^{9}$

I will now present Fernández Lagunilla's (1999) study for Spanish and Lobo's (2002, 2003) works on Portuguese.

\footnotetext{
7 Besides those mentioned in this work, there are some other studies that refer to Portuguese predicative gerunds which might be interesting to consider (cf. Móia \& Viotti (2005), Neto \& Foltran (2001), Arsénio (2010) and Ribeiro (2002)). However, due to space limitations, I will not discuss them in this present analysis.

${ }^{8}$ Casalicchio believes that Catalan microvariation in the use of predicative gerunds depends on the aspectual values carried by the gerund. Even though this is a valid hypothesis we could consider for EP, that does not seem to be the case (or at least it does not explain the differences between southern dialects and central and northern ones, since in these dialects all forms of the gerund with predicative value are ungrammatical).

${ }^{9}$ However, in line with what previous studies suggest, I assume that gerunds are CP's.
} 


\subsection{Fernández Lagunilla (1999)}

Regarding Spanish non-periphrastic gerunds, Fernández Lagunilla explains that there are two main different types: gerunds that modify a verb and gerunds that modify a clause.

7. Inés recitó el poema de Lorca temblando.
Inés recited the poem
'Inés recited Lorca's poem trembling.'
8. Inés recitó el poema de Lorca muy bien, aún estando enferma.
Inés recited the poem of Lorca very well yet being.GER ill

'Though ill, Inés recited Lorca's poem very well.'

According to the author, gerunds like (8) can precede the clause they modify, follow it or occur in different positions inside the clause, and no intonational changes occur. Gerunds like (7), on the other hand, normally occur after the verb, as the ungrammaticality of (10) shows.

9. Aún estando enferma, Inés recitó poema de

Yet being.GER ill Inés recited the poem of

Lorca muy bien.

Lorca very well

'Though ill, Inés recited Lorca's poem very well.'

10. *Temblando recitó el poema de Lorca.

Trembling.GER Inés recited the poem of Lorca

'Inés recited Lorca's poem trembling.'

The author also shows that when gerunds modify the entire clause, they can have a different subject, which is impossible when they modify a verb, as they can associate different adverbial modifiers from the ones that occur in the main clause, generate verbal periphrases, and allow a distinct negation from the main clause. ${ }^{10}$

\footnotetext{
${ }^{10}$ Fernández Lagunilla (1999) provides examples for each of these situations.
} 
Since this first division (between gerunds that modify the verb and gerunds that modify the clause) is not enough to explain some cases of gerunds that modify the verb, the author suggests another division among this last group: they can be either predicative or adjuncts. The former modifies the verb and the subject (just as adjectives or other predicative categories do) and the others only modify the verb, as the examples show:

11. Los niños de María lloran haciendo pucheros.

The kids of María cry making.GER pouts

'María's kids cry making pouts.'

12. Los niños de María lloran dándoles un grito.

The kids of María cry giving.them.GER a scream

'María's kids cry if we yell at them.'

Furthermore, according to Fernández Lagunilla these are the differences between the two constructions:

1. adjunct (i.e., adverbial) gerunds can precede the verb they modify without an emphatic interpretation

2. predicative gerunds associate with a NP in the main clause

3. predicative gerunds show aspectual restrictions

4. adverbial gerunds can undertake different aspectual meanings

5. predicative gerunds undertake a negative reading when the verb in the main clause is negated

6. a wider range of semantic values is associated with adverbial gerunds

Fernández Lagunilla states that predicative gerunds can range in types, depending on the constituent they modify. (11) above is an example of a gerund predicating on the subject. They can also predicate on the object and on a NP:

13. No soporto a ese cretino hablando de política.

Not stand at that cretin speaking.GER of politics

'I can't stand that cretin talking about politics.'

14. La llegada de María sonriendo fue muy comentada. 
The arrival of María smiling.GER was very commented

'The arrival of María smiling caused much comment.'

They can also be syntactically independent, as in the following example:

$\begin{array}{lll}\text { 15. iTú siempre pidiendo! } & \text { asking.GER } \\ \text { You always } & \text { alwa alwang!' } & \end{array}$

She draws attention to the fact that predicative gerunds that modify the subject and adjunct gerunds can easily be confused. This is an idea mentioned by other authors (cf. Lobo 2002, 2003) and the data that I have gathered also shows this to be the case. It is discussed in further detail later in this study.

\subsection{Lobo (2002, 2003)}

Following the work of Fernández Lagunilla for Spanish, Lobo explains that Portuguese has the same distinctions amongst predicative gerunds. These are some of the author's examples: they can predicate on the subject (cf. (16)), on the object (cf. (17)), occur inside a DP (cf. (18)) or be syntactically independent (cf. (19)):

16. 0 Zé entrou em casa cantando.

The Zé entered in home singing.GER

'Zé arrived home singing.'

17. $O$ Zé ouviu o Paulo cantando.

The Zé heard the Paulo singing.GER

'Zé heard Paulo singing.'

18. A cara da Ana olhando para o José não The face of.the Ana looking.GER at the José not

engana ninguém.

fool anyone

'Ana's face looking at José doesn't fool anyone.' 
Dialectologia. Special issue, $\boldsymbol{V}$ (2015), 351-371.

ISSN: 2013-2247

19. Os meninos dormindo a esta hora! Não posso acreditar. ${ }^{11}$

The kids sleeping at this hour not can believe

'The kids still sleeping! I can't believe it.'

Lobo also believes that it is sometimes difficult to distinguish between predicative gerunds (when they predicate on the subject) and adjunct gerunds. She claims, however, that there are two important differences. The first one is that only predicative gerunds, and not adjunct ones, show aspectual restrictions. They do not allow for verbs denoting non-phase states, such as estar 'to be', as example (20) shows. On the other hand, according to Lobo (21) is possible because it is an adverbial gerund:

20. *O João viu o Zé estando a viver em Paris.

The João saw the Zé being.GER to live in Paris

'João saw Zé living in Paris.'

21. O Zé perturbou a reunião estando constantemente a interromper.

The Zé disturbed the meeting being.GER frequently to interrupt

'Zé disturbed the meeting by being interruptive all the time.'

Also, note that as I have previously stated, according to Lobo only predicative gerunds allow for the construction $a$ +infinitive, where the preposition $a$ precedes the infinitive form of the verb (cf. (5) and (6)). I return to this in the next section when analysing data from CORDIAL.

\section{Data from CORDIAL-SIN}

Amongst the 2095 instances of gerunds that I have gathered, 54 were predicative gerunds. I was able to find examples of the different situations suggested by Lobo and

\footnotetext{
${ }^{11}$ The author explains that these independent gerunds can also be descriptive, as in Figo chutando a bola para Zacarias 'Figo passing the ball to Zacarias'. This is something that Fernández Lagunilla (1999) also mentions in the context of Spanish.
} 
Fernández Lagunilla: gerunds predicating on the subject (cf. (22)), on the object (cf. (23)), inside a DP (cf. (24)) and independent (cf. (25)): $:^{12}$

22. E depois abalavam por essas aldeias. And then went.away through those villages

cantando e dançando (...) CPT

singing.GER and dancing.GER

'And then they would go way through those villages, singing and dancing.'

23. Metia-se a água fervendo na murta. STE

One.put the water boiling.GER in.the myrtus

'We would put the boiling water over the myrtus.'

24. (...) vai o senhor padre com a gente lá toda rezando. STA

goes the sir Mr.? priest with the people there all praying.GER

'(...) goes the priest with everybody there praying.'

25. Ele acenando e eu lendo.

He waving.GER and I reading

'He was waving and I was reading.'

One interesting fact regarding the data is that even though the literature says that predicative gerunds do not allow for non-phase stative verbs (cf. Lobo, 2002, 2003), this dialectal corpus shows one example of predicative gerund co-occurring with estar 'to be':

26. Foram dar com ele estando estendido quase morto. ALV

Went give with he being.GER ranged almost dead

'They found him sprawled and almost dead.'

One single occurrence is of course not conclusive and does not allow for any solid interpretation. However, this seems to be worth studying in further detail in future work, and one could raise the hypothesis that in dialectal Portuguese such aspectual restriction does not apply to the same extent as in standard Portuguese.

As stated, some previous works on this topic have already mentioned that distinguishing between predicative gerunds and adverbial gerunds can sometimes be a

\footnotetext{
${ }^{12}$ All the examples from CORDIAL-SIN are identified at the end of each sentence by its location code.
} 
Dialectologia. Special issue, $\boldsymbol{V}$ (2015), 351-371.

ISSN: 2013-2247

difficult task. ${ }^{13}$ Accordingly, some tests to identify predicative gerunds have been suggested:

1. Position/mobility (Fernández Lagunilla 1999; Neto \& Foltran 2001)

2. Aspectual restrictions (Fernández Lagunilla 1999; Lobo 2002, 2003)

3. Negation: predicative gerunds undertake a negative reading when the verb in the main clause is negated (Fernández Lagunilla 1999)

4. Possibility of a+infinitive (Lobo 2002, 2003)

5. Predicative gerunds answer questions like "How was $\mathrm{x}$ when [main clause"]; adverbial ones answer questions like "How did/does x main clause" (Fernández Lagunilla 1999)

6. Predicative gerunds can be replaced by adjectival constituents; adverbial gerunds can be replaced by adverbial ones (Fernández Lagunilla 1999)

The dialectal data from CORDIAL has also proven this to be a difficult task. Although the possibility of the construction a+infinitive - the test suggested by Lobo for EP - has been the test I followed in order to identify predicative gerunds, the results of this test were not always clear. In some cases there were no doubts about the results, and the possibility of a construction with a+infinitive made me consider cases like these as predicative gerunds. When they produced unsatisfactory results with a+infinitive, it was interpreted as a proof that the construction was an adverbial gerund, so they were disregarded. In some other cases, however, the results were not clear, since there were doubts regarding the acceptability of some examples. ${ }^{14}$ Even though some doubts persisted, I considered these cases predicative gerunds due to the fact that the construction a+infinitive (the test that I have been following) is not completely ungrammatical. The important thing to note here is that this distinction can sometimes indeed be difficult and there are some factors regarding the tests that have been mentioned in the literature that I think are worth mentioning.

\footnotetext{
13 Fernández Lagunilla (1999) also mentions another kind of difficulty: some structures can be ambiguous and fall between a predicative gerund and a periphrastic construction. I found some cases like these in CORDIAL-SIN, which I disregarded due to that structural ambiguity.

${ }^{14}$ Furthermore, the application of the other tests did not always help to identify these structures.
} 
Let us first consider some problems related to the ante-position test. Both Fernández Lagunilla (1999) and Lobo (2002, 2003), and also Arsénio (2010), observe that one of the properties of predicative gerunds is that they resist anteposition. Although this is actually true, the problem is that the authors claim that something different happens with adverbial gerunds, which, according to them, allow for anteposition: this would therefore be a difference between the two structures. These are examples from Lobo (2006):

27. ?Coxeando, o João chegou a casa.
Limping.GER the João got at home
'João got home limping.'

28. Arrombando a porta com um maçarico, os ladrões Breaking.GER the door with a blow.torch the thieves entraram em casa.

entered in house

'Breaking down the door, the thieves managed to get inside the house.'

Lobo notes, however, that adverbial gerunds that modify the verb normally occur at the end of the clause, or exceptionally at first position, but in this case some alterations in meaning take place (cf. Lobo 2003). This is where the problem resides: the adverbial gerunds that can easily be confused with predicative gerunds are the ones that modify the verb just as in the example above. If both structures resist moving to first position, as I think is clear in (29b) and (30b) - the result is unnatural in both predicative and adverbial gerunds. This cannot be a test used to distinguish predicative gerunds from adverbial ones:

29. a. O João entrou na sala cantando.

The João entered in.the room singing.GER

'João entered the room singing.'

b. \#Cantando, o João entrou na sala.

Singing.GER the João entered in.the room

'João entered the room singing.'

30.

a. Os bombeiros alertaram-nos tocando a sirene.
The firefighters warned.us playing.GER the siren


Dialectologia. Special issue, $\boldsymbol{V}$ (2015), 351-371.

ISSN: 2013-2247

'The firefighters warned us by playing the siren.'

b. \#Tocando a sirene, os bombeiros alertaram-nos.

Playing.GER the siren the firefighters warned.us

'The firefighters warned us by playing the siren.'

I would now like to advance some ideas regarding the a+infinitive test. According to Lobo, all predicative gerunds allow for an a+infinitive alternative construction, as in example (5) above, which I reproduce in (31):

31. 0

João chegou a casa coxeando

/ $a$

coxear.

The João arrived at home limping.GER to.PREP limp.INF

'João came home limping.'

I believe, in fact, that most predicative gerunds allow for such a construction, not because of their predicative nature, but for aspectual reasons. In line with what Móia and Viotti (2005) defend, I believe that a+infinitive is only possible when there is temporal overlapping between the main clause and the gerund clause. Since this condition is present most of the time with predicative gerunds, they can normally alternate with a+infinitive. That's what happens in (31). The need for this temporal overlapping is clear in examples (32) and (33), where the punctual events (espirrar 'sneeze' and soluçar 'sob') are necessarily interpreted as iterative so they can overlap the event denoted by the main clause:

32. O João entrou em casa espirrando.

The João entered the house sneezing.GER

'João was sneezing when he got home.'

33. O professor leu o poema soluçando.

The teacher read the poem sobbing

'The teacher was sobbing while reading the poem.' 
Furthermore, according to Lobo, adverbial gerunds should not allow for $a+$ infinitive constructions. Examples (34) and (35) show that this might not always be true: these structures, easily interpreted as adverbials, allow for $a+$ +infinitive: ${ }^{15}$

34. Os governantes enriqueceram a roubar dinheiro.

The governors got.richto.PREP steal.INF money

'The governors get rich by stealing money.'

35. As empresas evitama falência a despedir pessoas.

The businesses avoid the bankruptcy to.PREP fire.INF people.

'Businesses avoid bankruptcy by firing people.'

This exposition highlights that it is indeed difficult to distinguish between predicative gerunds and adverbial gerunds, and emphasizes that there can be some problems with the tests that have been identified. Regarding the a+infinitive test suggested by Lobo for EP, even if it is a useful test that is normally succesful, I argue that it can be fallible, because it is only applicable to constructions with temporal overlapping.

\subsection{Areal distribution}

It is interesting to notice that all the instances of predicative gerund found in CORDIAL-SIN were attested in a well-defined geographical area. These constructions were mainly found in southern regions of Portugal and in the islands (in northern Portugal, only one non-ambiguous example was found, which I assume to be an extension of the Galician area, where these constructions also exist).

Also interesting is the fact that this geographical distribution is very similar to the one identified for Carrilho and Pereira (2011) regarding the periphrastic construction estar+gerund:

\footnotetext{
${ }^{15}$ Note that the answering test suggested by Fernández Lagunilla can also raise problems. If we consider a sentence like "A Ana entrou cantando", since this is a typical example of predicative gerund we should be able to formulate a question such as "Como estava a Ana quando entrou?" How was Ana when she arrived?". However, this is not a natural question in EP for that kind of sentence. On the other hand, a question like "How did x [main clause]", normally used for adverbial contexts, can be used with a sentence like $A$ Ana entrou cantando 'Ana arrived singing', which proves that it is possible to use it not only in adverbial contexts but also in predicative contexts.
} 
Dialectologia. Special issue, V (2015), 351-371.

ISSN: 2013-2247

36. Essa pessoa estava varrendo, limpando (LUZ)

That person was sweeping cleaning

'That person was sweeping, cleaning.'

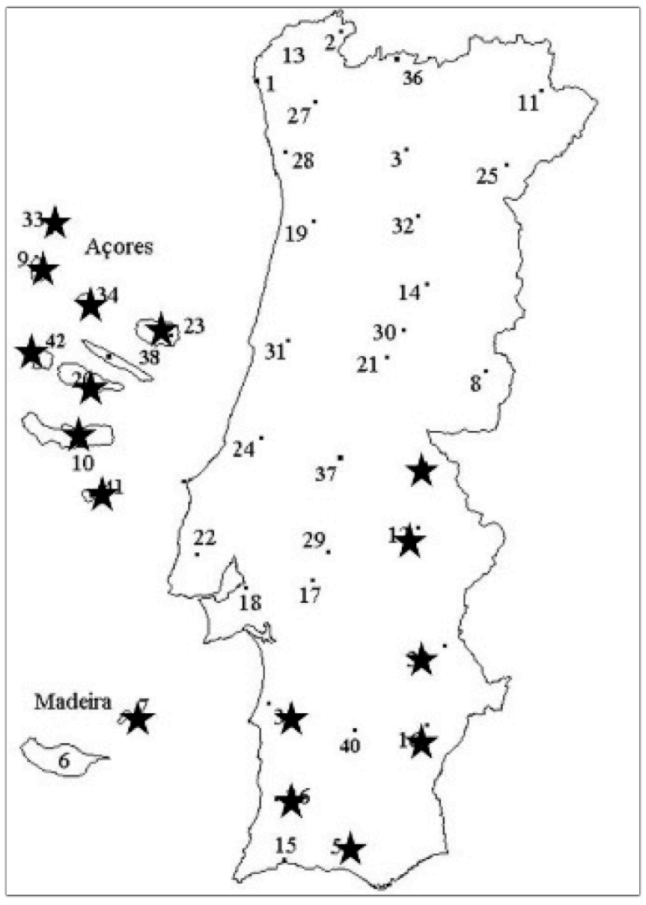

Figure 1. Predicative gerunds

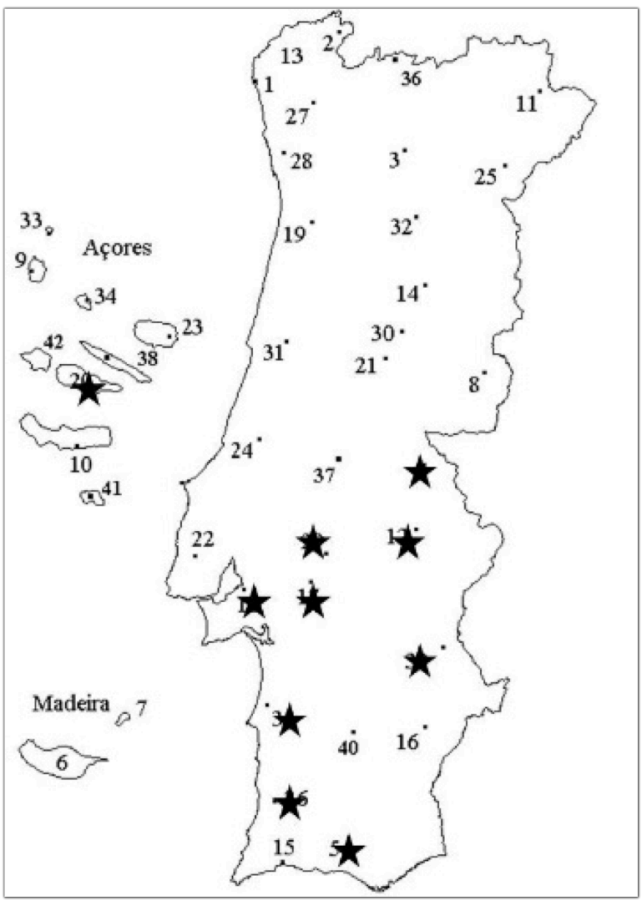

Figure 3. Inflected gerunds (adapted from Lobo 2008)

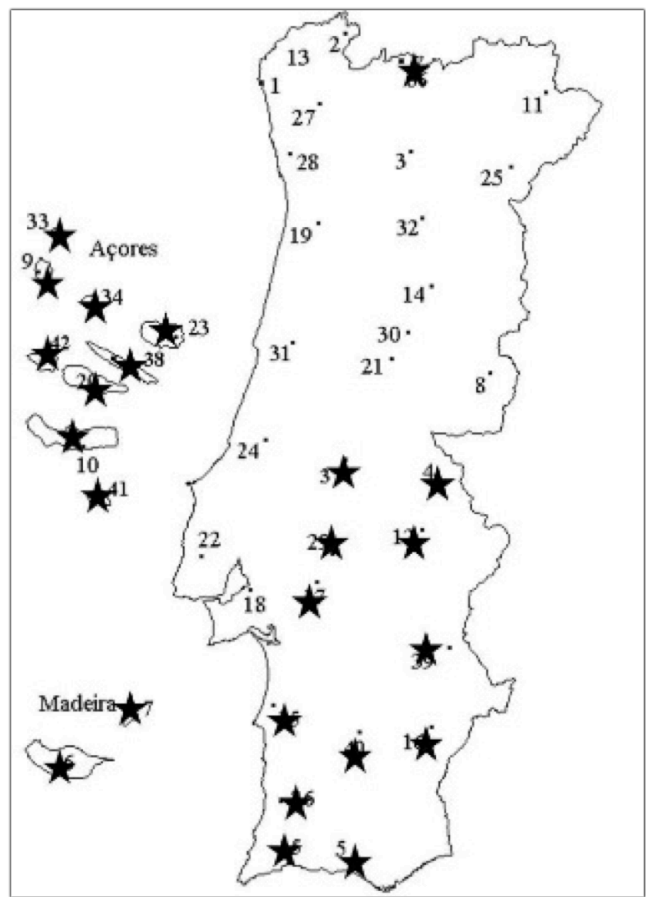

Figure 2. Estar 'to be'+GER (adapted from Carrilho \& Pereira 2011)

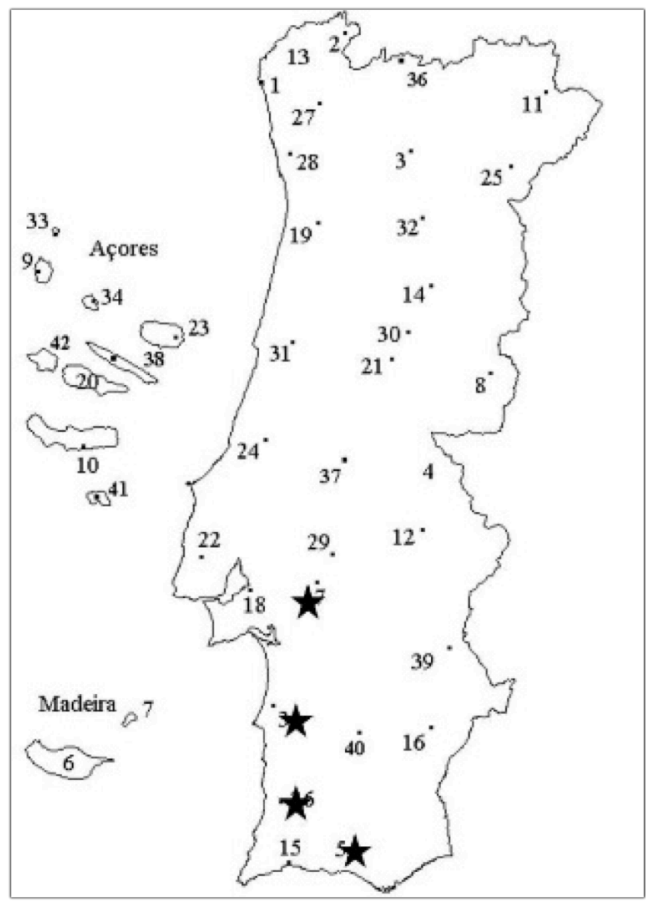

Figure 4. Quando ‘when'+GER 
In fact, this data is relevant in different ways. On one hand, it is worth noting that previous works (cf. Carrilho \& Pereira 2011; Lobo 2008) and Pereira (in preparation) suggest that many specific constructions with the gerund tend to occur in southern Portuguese territory and sometimes in the islands. That is the case of estar+gerund above, inflected gerunds (Lobo 2008) and adverbial gerunds introduced by quando 'when' and em bem 'in well' (cf. Pereira, in preparation):

37. E tendem uma árvore, não há pássaro

And having.INFL.GER one tree not there.is bird

nenhum que poise no chão. (STJ)

any that lands on.the floor

'And if there is a tree, no bird lands on the floor.'

38. Quando passando aqui o segundo, já não sai. (MLD)

When passing.GER here the second already not gets.out

'Once the second one passes here, it doesn't come out anymore.'

39. A gente em bem apanhando um sapo,enfiávamos

The people in well catching.GER a frog sticked.1PL

lá os pés dentro. (STJ)

there the feet inside

'When/if we caught a frog, we would stick our feet inside of it.'

In accordance with what previous works have shown, this leads us to a first conclusion, which is that gerund constructions are particularly productive in the south (and in some islands) of Portugal, where both the gerund and the a+infinitive form are possible. In the Northern dialects, on the other hand, all these specific constructions with gerund were not found. This suggests that there is a clear dialectal division in EP when it comes to the use of gerunds versus a+infinitive.

On the other hand, as becomes clear in Pereira (in preparation), the analysis of several non-standard constructions identified in CORDIAL-SIN shows that it is possible to identify different types of syntactic areas in Portugal. One of the basic and more recurrent divisions is the one that opposes the North to the South and the islands: which is the area where these constructions with gerund (including the predicative 
gerund) were found. Below I present the syntactic area that shows this kind of division. It is the distribution that I have identified for several constructions with gerund (estar 'to be'+GER, inflected gerunds, predicative gerunds and some adverbial gerunds) and also instances of existential estar. ${ }^{16}$

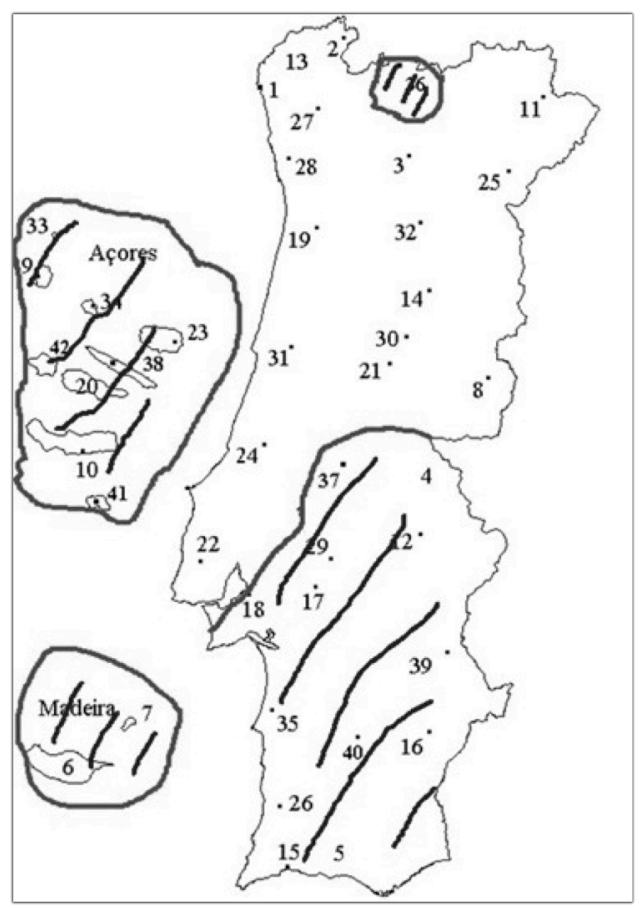

Figure 5. Em bem 'in well'+GER

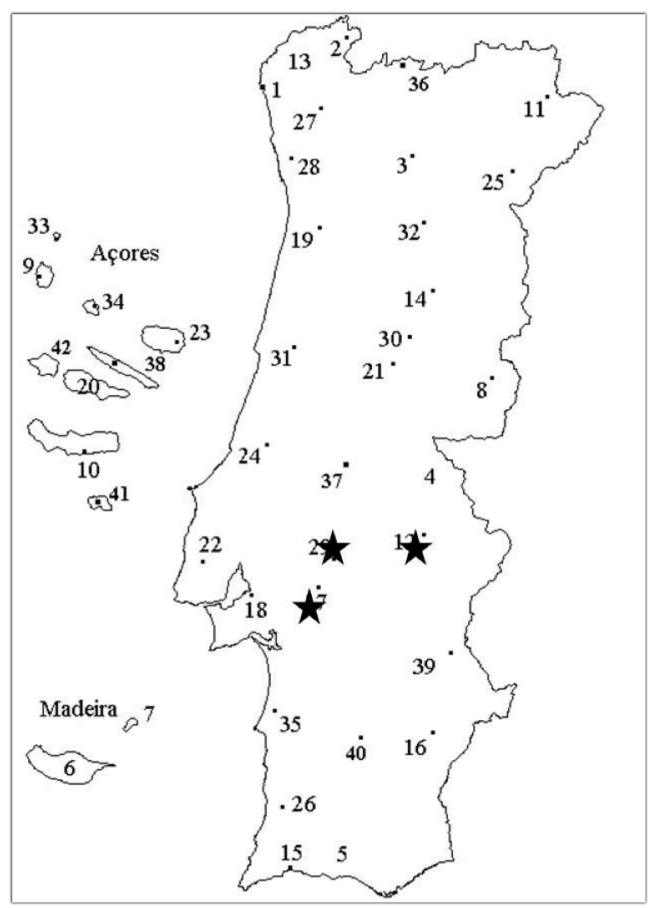

Figure 6. Portuguese syntactic area: Northern dialects versus Southern/insular dialects

This data is useful because they provide additional evidence for this type of syntactic division.

Geographic distribution of predicative gerunds seems therefore to be not necessarily casual and geolinguistically relevant. This is what I will briefly discuss in the next section.

\footnotetext{
${ }^{16}$ In standard Portuguese, existential constructions normally occur with the impersonal haver 'to have'. I noticed that in some Portuguese dialects, however, the verb estar 'to be' can be used to express this value.
} 


\subsection{Portuguese predicative gerunds: some notes on the geographical distribution and} diachronic considerations

As we have seen above, the geographical distribution of predicative gerunds leads us to divide Portuguese dialects into two groups. One group of dialects (northern and central dialects) where the predicative gerund does not occur, using instead a prepositional infinitive (a+infinitive); and a group of varieties (south and islands) where both the prepositional infinitive and gerunds occur in the same contexts.

As mentioned above, these northern and central dialects (or those that use only $a+$ infinitive in predicative contexts), also employ prepositional infinitives in verbal periphrases with aspectual verbs like estar 'to be', as is well known in the literature (except for some particular verbs, as CORDIAL makes clear). ${ }^{17}$ What is not so well known, but what this corpus seem to suggest (cf. Pereira, in preparation), is that those northern varieties also tend to use fewer adverbial gerunds than the southern dialects, making use of other strategies instead. ${ }^{18}$

Although the use of prepositional infinitives in standard Portuguese to express progressive constructions and predicative structures is well known, the idea that they also use less adverbial gerunds is, as stated, something that has not been mentioned in the literature. This data suggests that these dialects at some point started replacing gerund constructions with prepositional infinitives (or other alternative constructions, as in the case of adverbial gerunds), and highlight the idea that there is a very clear dialectal division in European Portuguese when it comes to the use of gerunds and the alternation with other infinitive forms (normally $a+$ infinitive).

Regarding this a+infinitive versus gerund alternation, some diachronic notes and the comparison with other languages will shed some light on the situation. It is well known that the construction a+infinitive was a relatively recent innovation from EP, which started occurring presumably in the XVIII century (cf. Cunha \& Cintra 1986;

\footnotetext{
${ }^{17}$ CORDIAL shows that some verbal periphrasis with movement verbs are constructed with gerunds, but not a+infinitive, all over Portuguese territory (this is a structure productive in both standard and nonstandard Portuguese).

${ }^{18}$ While some Southern dialects use gerunds in adverbial contexts to express, for instance, condition and time, these constructions, also available in the Northern ones (except for when there are connectors introducing the gerund clause, something frequent in Southern dialects but ungrammatical in other regions of Portugal), are considerably less productive in the North.
} 
Dialectologia. Special issue, $\boldsymbol{V}$ (2015), 351-371.

ISSN: 2013-2247

Barbosa, 1999; Mendes Mothé 2004). This is something that did not take place exclusively in EP: as many works show, the evolution of prepositional infinitives took place cross-linguistically across the Romance languages over the last centuries (cf. Shulte 2007; Casalicchio 2013, among others). What seems to be the case in Portugal, as stated above, is that at some point of the evolutionary process some dialects (mostly the Northern ones, as CORDIAL suggests) started using a+infinitive at least in two contexts: predicative and progressive constructions. The exceptions would be progressive periphrastic constructions with movement verbs.

Northern dialects seem therefore to have lost the gerund construction initially used in these contexts: the one derived from Latin. Apparently, they also started restricting the use of adverbial gerunds.

While the evolution seems to have led to the abolition of gerunds in predicative and progressive constructions in northern dialects, predicative and progressive gerunds resisted in southern dialects (and in some islands). These dialects also allow the use of $a+$ infinitive (due to the influence of the northern dialects or due to a parallel innovation).

It is worth noting that a similar situation happened in some Italian dialects. In a work on non-finite perceptive constructions in Northern Italy, Casalicchio (2012) mentions a stage in the evolutionary process where some dialects (like Noneso) started replacing the gerund with prepositional infinitives in any context (including adverbial ones). Since prepositional infinitives started occurring all over Romance in the last centuries (cf. Casalicchio 2013), I believe that this data from Portuguese provides evidence for the theory of a parallel evolution among the Romance languages regarding the replacement of gerunds by prepositional infinitives during the last centuries.

\section{Final remarks}

In this work I have analysed predicative gerund constructions found in dialectal Portuguese. I started by characterizing the structures encountered, following 
Fernández Lagunilla's (1999) work for Spanish and Lobo's (2002, 2003) study for Portuguese. Considering the data I had gathered, I addressed some aspects concerning the well-known ambiguity between predicative gerunds and adverbial ones: I made some observations regarding the typical tests used to distinguish both structures and suggested that the Portuguese test proposed by Lobo (the possibility of a+infinitive constructions in predicative gerunds) requires caution in its application, since it is only possible when there is temporal overlapping between the gerund clause and the main clause.

I have shown that predicative gerunds are only productive in some southern and insular dialects within the Portuguese territory, revealing the existence of a confined geographical area. As noted, they were identified within the same area identified for other constructions with gerunds and I believe they constitute an additional argument for the existence of a syntactic area in Portugal which opposes northern dialects to southern/insular dialects.

Since the northern dialects use a+infinitive in these predicative contexts - an innovation of these dialects that took place over the last few centuries - and seem to have lost the gerund forms (that derive from Latin) in these and other contexts, which only seem to have survived in Southern and insular dialects, I argue that standard Portuguese and dialectal Portuguese were under distinct diachronic evolutions regarding this topic, and that different evolution led to the loss of predicative gerunds in the northern Portuguese dialects, similar to what happened with other Romance languages.

\section{References}

ARSÉNIO, M. M. (2010) Construções gerundivas no português europeu e brasileiro, PhD Dissertation, Faculdade de Letras da Universidade de Lisboa.

BARBOSA, A. G. (1999) Para uma história do português colonial: aspectos lingüísticos em cartas de comércio, PhD Dissertation, Universidade Federal de Rio de Janeiro.

Borgonovo, C. (1996) “Gerunds and Perception Verbs", Langues et Linguistique, 22, 1-19.

CASALICCHIO, J. (2012) "The Syntax of Gerunds and Infinitives with Perception Verbs in Northern Italy", Poster, Leiden University, 24-26 May 2012. 
Dialectologia. Special issue, V (2015), 351-371.

ISSN: 2013-2247

CASALICCHIO, J. (2013) Pseudorelative, gerundi e infiniti nelle varietà romanze: affinità (solo) superficiali e corrispondenze strutturali, München: Lincom Europ.

CARRILHO, E. \& S. PeREIRA (2011) “Sobre a distribuição geográfica de construções sintácticas nãopadrão em Português europeu", XXVI Encontro Nacional da Associação Portuguesa de Linguística, Lisboa: APL, 125-138.

CUNHA, Celso (1986) "Conservação e Inovação no Português do Brasil", O Eixo e a Roda: revista da literatura brasileira, 5, 199-232.

DI TULLIO, Ángela L. (1998) “Complementos no flexivos de verbos de percepción física en español", Verba, 25, 197-221.

FeRNÁNDEZ LAGUnilLA, M. (1999) "Las construcciones de gerundio", in Ignacio Bosque \& Violeta Demonte (eds.), Gramática Descriptiva de la Lengua Española, Madrid: Real Academia Española-Espasa, vol. 2, 3443-3503.

LOBO, M. (2002) "Aspectos da sintaxe das orações gerundivas adjuntas do Português", XVII Encontro Nacional da Associação Portuguesa de Linguística, Lisboa: APL, 247-265.

Loвo, M. (2003) Aspectos da Sintaxe das Orações Subordinadas Adverbiais do Português, PhD Dissertation. Faculdade de Ciências Sociais e Humanas da Universidade Nova de Lisboa.

LOBO, M. (2008) "Variação morfo-sintáctica em dialectos do Português europeu: o gerúndio flexionado", Diacrítica, 22-1, 25-55.

MóıA, T. \& E. Viotti (2005) "Sobre a semântica das orações gerundivas adverbiais", Actas do XX Encontro Nacional da Associação Portuguesa de Linguística, Lisboa: APL, 715-729.

Mothé, N. G. M. (2004) “A Variação Histórica entre a Forma Nominal Gerúndio e o Infinitivo Gerundivo: o Português Brasileiro e o Português Europeu em Contraste", Revista Inicia, 1, 152-159.

Neto, J. B. \& M. J. Foltran (2001) "Construções com gerúndio", Actas do XVI Encontro da Associação Portuguesa de Linguística, Coimbra: APL, 725-735.

PereIRA, S. A. (in preparation) Áreas sintáticas no território português. PhD dissertation. Faculdade de Letras da Universidade de Lisboa.

RIBEIRO, R. (2002) As ocorrências da forma de gerúndio na variedade padrão e numa variedade dialectal do Português Europeu, MA Dissertation. Faculdade de Ciências Sociais e Humanas da Universidade Nova de Lisboa.

SCHULTE, K. (2007) Prepositional Infinitives in Romance: A usage-based approach to syntactic change, Oxford/Berne: Peter Lang. 